\title{
HUBUNGAN ANTARA POLA ASUH DENGAN GAYA HIDUP HEDONIS PADA REMAJ A
}

\author{
Khaleda Putri Arini ${ }^{1, a)}$, Uswatun Hasanah ${ }^{1, b}$, Metty Muhariati ${ }^{1, c)}$

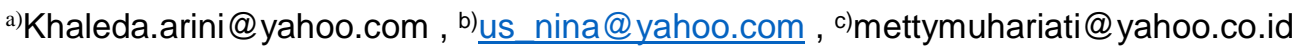 \\ 1P rogram Studi Pendidikan Kesejahteraan Keluarga \\ Fakultas Teknik, Universitas Negeri J akarta \\ J In. Rawamangun Muka, J akarta Timur.13220
}

\begin{abstract}
Abstrak
Moral yang baik terbentuk dari pendidikan moral yang diberikan dalam pola asuh orang tua. Moral yang baik akan menghasilkan perilaku dan keputusan yang baik dalam menjalani hidup. Gaya hidup hedonis ini merupakan cara seseorang menghabiskan waktu dan mengekspresikan diri dengan kesenangan yang menjadi tujuan utama hidup. Tujuan penelitian ini adalah untuk mengetahui dan menganalisis hubungan antara pola asuh dengan gaya hidup hedonis pada remaja di SMAN 9 Bogor. Penelitian ini adalah penelitian kuantitatif dengan metode survey dan pendekatan korelasional. Populasi penelitian ini adalah seluruh siswa kelas XI SMAN 9 Bogor dengan jumlah sampel penelitian sebanyak 170 responden. Pengujian hipotesis menggunakan analisis Product Moment. Hasil perhitungan koefisien korelasi Product Moment menghasilkan Thitung sebesar 0,205. Hasil Uji t pada koefisiennya sebesar $=2,72>$ tabel $=1,974$. Hal ini menjelaskan bahwa terdapat hubungan yang positif dan signifikan antara pola asuh dengan gaya hidup hedonis pada remaja. Besarnya koefisien determinasi pola asuh sebanyak $4,21 \%$ terhadap gaya hidup hedonis sedangkan sisanya $95,79 \%$ ditentukan oleh variabel lain yang tidak diteliti.
\end{abstract}

Kata kunci: Pola asuh, gaya hidup hedonis, remaja

\section{Abstract \\ Relationship Between Parenting with Hedonist Lifestyle in Adolescents}

Good moral formed from moral education provided in the parenting parents. Good moral behavior will produce good decisions in life. This hedonistic lifestyle is the way a person to spend time and to express themselves with pleasure is the main purpose of life. The study aims to identify and analyze relationship between parenting with hedonist lifestyle in adolescents of student SMAN 9 Bogor. This research is a quantitative research with survey method with the correlation approach. The population of this study was all students in grade XI in SMAN 9 Bogor. The amount of sample in this study is about 170 respondents. Hypotheses testing using analysis Product Moment. The results of product moment correlation coefficient calculation produce $T_{\text {count }}$ at 0.205 . T-test results on coefficient of t-test $=2.72>$ table $=1.974$ is significant. It is clear that there is a positive and significant relationship between parenting with hedonist lifestyle in adolescents. The coefficient of determination parenting as much as $4.21 \%$ while the remaining $95.79 \%$ is determined by other variables not examined.

Keywords: Parenting, Hedonist Lifestyle, Adolescents. 


\section{PENDAHULUAN}

Dewasa ini kehidupan masyarakat banyak memiliki beberapa gaya hidup. Bermacammacam gaya hidup dipilih oleh masing-masing individu untuk menghabiskan waktu dan melakukan kegiatan yang mereka senangi. Ditambah lagi dengan lingkungan sosial yang semakin mendukung terbentuknya gaya hidup pada seorang individu. Salah satu gaya hidup yang akan peneliti bahas dalam penelitian ini adalah gaya hidup hedonis. Dalam menentukan gaya hidup masing-masing individu didasari oleh sikap dan perilaku yang dimiliki oleh seorang individu itu sendiri. Baik atau tidaknya sebuah keputusan yang diambil oleh seorang individu didasari dari moral yang dimiliki oleh masing-masing individu. Moral yang baik akan menghasilkan perilaku dan keputusan yang baik dalam menjalani hidup.

Moral yang baik terbentuk dari pendidikan moral yang diberikan dalam pola asuh orang tua. Pola asuh menurut Baumrind yang dikutip oleh Yusuf, mendefinisikan pola asuh sebagai pola sikap atau perlakuan orang tua terhadap anak yang masing-masing mempunyai pengaruh tersendiri terhadap perilaku anak antara lain terhadap kompetensi emosional, sosial, dan intelektual anak (Yusuf, 2004: 51). Pola asuh yang diberikan orang tua sangatlah berpengaruh kepada perkembangan anak sampai dengan perilaku yang akan anak miliki. Penanaman nilai- nilai moral yang positif pada akan berdampak positif untuk perilaku anak.

Menurut Kottler dalam Sakinah (2002: 78) gaya hidup menggambarkan keseluruhan diri seseorang yang berinteraksi dengan lingkungannya. Hal ini berarti gaya hidup adalah perpaduan antara kebutuhan ekspresi diri dan harapan kelompok terhadap seseorang dalam bertindak berdasarkan pada norma yang berlaku. Dan hedonis adalah etika atau pandangan yang menganggap kesenangan adalah kenikmatan sebagai tujuan hidup (Surbakti, 2009: 238). Gaya hidup hedonis ini merupakan cara seseorang menghabiskan waktu (aktivitas yang dilakukan) dan mengekspresikan diri dengan pandangan kesenangan yang menjadi tujuan utama hidup.

Gaya hidup hedonis dapat timbul dengan diawali dengan sifat ingin menduplikasi apa yang dilakukan orang lain untuk mendapatkan pengakuan dari lingkungan sosialnya atau sebagai pembuktian status sosial yang dimiliki seorang individu. Ditambah dengan faktor pemicu lain yang ada di luar individu seperti pola asuh moral orang tua terhadap anak, derasnya arus globalisasi yang dihadapi oleh remaja, pergaulan teman sebaya, dan trend yang sedang booming saat ini. Sebaliknya apabila kemungkinan gaya hidup hedonis dapat terjadi.

Seiring perkembangnya teknologi yang semakin mudah untuk di akses oleh anak, peran orang tua sangatlah penting dalam pengasuhan seorang anak sampai pada fase tahapan usia remaja agar mampu membentuk remaja yang baik kepribadiannya. Memiliki anak yang memiliki moral dan kepribadian yang baik merupakan dambaan setiap orang tua. Maka dari itu orang tua harus mampu mengerti dan memahami tipe pribadi anak. Masing-masing tipe pribadi anak tidak dapat dibimbing dalam pola asuh yang sama. Untuk mencapai perkembangan anak yang optimal, seseorang anak membutuhkan pemenuhan kebutuhan fisik, psikologis, dan sosial. Kebutuhan psikologis yang utama adalah pemenuhan afeksi, kognisi, dan moral untuk mengembangkan kemampuan intelektual, emosional, dan sosial. Untuk mencapai tingkat perkembangan tersebut dibutuhkan suatu pola atur atau caring techniques yang sesuai dengan karakteristik anak. Setiap orang tua mempunyai kondisi yang berbeda sesuai dengan berbagai faktor yang berpengaruh dan membentuk kemampuan serta keterampilannya dalam mengasuh dan mendidik anak- anaknya (Styles of Raising Children) (Geraldine K, dkk, 2003: 24).

Meningkatnya perkembangan usaha yang semakin pesat belakangan ini yang tidak lagi hanya berkembang di kota-kota besar lagi namun sudah mulai memasuki kota- kota kecil. Salah satu area bisnis yang menyebabkan pendapatan perkapita meningkat adalah semakin banyaknya pembangunan tempat hiburan yang tersebar di Indonesia. Dengan meningkatnya pendapatan per kapita di Indonesia, maka makin meningkat pula kebutuhan hidup masing-masing individu. Dari sekian banyak kebutuhan yang dibutuhkan masing-masing individu seperti kebutuhan primer, sekunder, dan eksistensialisme. Namun, seiring meningkatnya pendapatan dan kebutuhan makin 
tinggi pula tekanan dalam status sosial masyarakat yang menyebabkan individu menjadi manusia yang memiliki gaya hidup tinggi perilaku hedonis.

Kelompok usia remaja merupakan kelompok usia yang sedang berada pada periode transisi perkembangan antara masa kanak- kanak menuju masa dewasa yang melibatkan perubahanperubahan biologis, kognitif, dan sosio- emosional (Santrock, 2007). Pada masa-masa tersebut, para remaja sedang berada pada tahap pencarian identitas sehingga mereka biasanya menciptakan sesuatu yang berbeda, baik dari sisi pakaian, gaya rambut, cara berdandan, maupun bertingkah laku. Remaja juga cenderung untuk memiliki keingintahuan yang lebih akan hal-hal yang baru sehingga mereka tidak ragu untuk mencobanya. Selain itu, remaja biasanya mudah dipengaruhi oleh rayuan iklan, mudah dipengaruhi oleh perubahan, serta cenderung boros dalam menggunakan uangnya. Remaja saat ini yang hidup di era globalisasi, dimana di era ini informasi sangat mudah untuk di akses di media sosial. Perkembangan pembangunan yang pesat menimbulkan makin maraknya tempat hiburan seperti cafe, mall, restoran, dll.

Pada fase kehidupan remaja terdapat banyak sekali permasalahan yang timbul, seperti kenakalan remaja, makin jauhnya hubungan dengan orang tua karena pengaruh peer group. Pada fase ini remaja lebih mendengar dan menghargai apa yang dikatakan teman bukan apa yang dikatakan orang tua. Di tahap ini moral yang dimiliki anak akan menentukan perilaku anak pada fase ini.

Berdasarkan latar belakang dan permasalahan tersebut, peneliti bermaksud melakukan penelitian dengan memfokuskan pada gaya hidup hedonis remaja.

\section{METODE PENELTIAN}

Penelitian dilaksanakan di SMAN 9 BOGOR, tempat penelitian ditentukan karena berbagai kriteria penelitian yang memenuhi syarat pada penelitian yang akan dilaksanakan. Beberapa kriteria responden yang menjadi tolak ukur dalam pemilihan tempat penelitian yaitu; kriteria usia remaja, siswa dari kalangan menengah yang sangat berpotensi memiliki gaya hidup hedonis, lingkungan sekolah yang berada di tengah kota dan sangat dekat dari salah satu pusat perbelanjaan terlaris di Kota Bogor. Penelitian ini adalah penelitian kuantitatif dengan metode survey dan pendekatan korelasional. Populasi penelitian ini adalah seluruh siswa kelas XI SMAN 9 Bogor dengan jumlah sampel penelitian sebanyak 170 responden. Pengujian hipotesis menggunakan analisis Product Moment.

\section{HASIL DAN PEMBAHASAN}

Kottler dalam Sakinah (2002:78) menjelaskan bahwa gaya hidup menggambarkan keseluruhan diri seseorang yang berinteraksi dengan lingkungannya. Hal ini berarti gaya hidup adalah perpaduan antara kebutuhan ekspresi diri dan harapan kelompok terhadap seseorang dalam bertindak berdasarkan pada norma yang berlaku. Oleh karena itu banyak diketahui macam gaya hidup yang berkembang di masyarakat sekarang misalnya gaya hidup hedonis, gaya hidup metropolis, dan lainnya di masyarakat lainnya.

Gaya hidup hedonis menurut Epikurus dalam Russell (2004) adalah suatu paham yang menganggap kesenangan dan kenikmatan materi adalah tujuan yang paling utama dalam hidup. Bagi para penganut paham ini, bersenang-senang, pesta pora, dan pelesiran merupakan tujuan utama hidup. Gaya hidup hedonis adalah pola hidup yang mengarahkan aktivitasnya untuk mencari kesenangan hidup, sehingga bentuk perilaku yang dimunculkan dalam perilaku hedonis biasanya lebih banyak menghabiskan waktu diluar rumah untuk bersenang- senang dengan temantemanya, senang membeli barang yang tidak diperlukan, dan selalu ingin menjadi perhatian di lingkungan sekitarnya.

Secara umum ada dua faktor yang menyebabkan seorang remaja bahkan sampai masyarakat memiliki gaya hidup hedonisme. Yaitu faktor ektern yang meliputi media dan lingkungan 
sosial, bahkan pola asuh serta faktor intern yang meliputi keyakinan dalam beragama, perkembangan psikologis remaja dan masing masing individu.

Faktor yang mempengaruhi gaya hidup adalah konsep diri. konsep diri yang baik akan menghasilkan gaya hidup yang baik untuk seorang manusia, begitupun sebaliknya. Konsep diri dibentuk dalam perjalanan hidup seorang anak dari berbagai lingkungan seperti lingkungan sekolah, lingkungan keluarga, dan lingkungan sosial anak. Sekolah utama seorang anak untuk mendapatkan pendidikan adalah keluarga, dan pembentukan konsep diri yang baik adalah tanggung jawab orang tua dari refleksi hasil pengasuhan anak selama ini hingga membentuk sikap maupun perilaku.

Pola asuh sebagai perlakuan orang tua terhadap anak mempunyai pengaruh tersendiri terhadap perilaku anak antara lain terhadap kompetensi emosional, sosial, dan intelektual anak (Yusuf,2004: 51). Pola asuh adalah pola pengasuhan anak yang berlaku dalam keluarga, yaitu bagaimana keluarga membentuk perilaku generasi berikut sesuai dengan norma dan nilai yang baik dan sesuai dengan kehidupan masyarakat.

Berdasarkan penelitian yang telah dilakukan, diketahui thitung $=2,720>$ ttabel $(1,974)$. nilai koefisien pola asuh dengan gaya hidup hedonis, sehingga dapat disimpulkan bahwa terdapat hubungan antara pola asuh dengan gaya hidup hedonis pada remaja. Adanya hubungan pada pola asuh dengan gaya hidup hedonis memang sejalan dan sependapat dengan apa yang dinyatakan oleh Loudan dan Bitta dalam Nadzir (2015: 586) mengenai faktor-faktor yang mempengaruhi gaya hidup hedonis salah satunya adalah keluarga. Dan diperkuat lagi dengan pendapat Kotler (1997) di dalam Nadzir (2015: 587) bahwa keluarga memegang peranan terbesar dan terlama dalam pembentukkan sikap dan perilaku individu. Hal ini karena pola asuh orang tua akan membentuk kebiasaan anak yang secara tidak langsung mempengaruhi pola hidupnya.

Berdasarkan besaran korelasinya antara pola asuh dengan hedonis sebesar 0,205 artinya memiliki hubungan yang positif dan masuk ke dalam kategori rendah. Dari hasil tersebut mengindikasikan bahwa pola asuh memiliki hubungan yang rendah dengan hedonisme dikarenakan tidak semua remaja memiliki gaya hidup hedonisme. Dapat juga dikarenakan oleh faktor lain seperti pendidkan, pergaulan, dll.

Berdasarkan penelitian yang telah dilakukan besaran korelasinya antara pola asuh demokratis dengan hedonis sebesar 0,158 artinya memiliki hubungan yang positif dan masuk ke dalam kategori rendah. Dari hasil tersebut mengindikasikan bahwa pola asuh demokratis memiliki hubungan yang rendah dengan hedonisme dikarenakan tidak semua jenis pola asuh memilki keterkaitan dengan gaya hidup hedonisme. Dapat juga dikarenakan oleh faktor lain seperti pendidikan, pergaulan, dll.

Berdasarkan penelitian yang telah dilakukan besaran korelasinya antara pola asuh otoriter dengan hedonis sebesar 0,217 artinya memiliki hubungan yang positif dan masuk ke dalam kategori rendah. Dari hasil tersebut mengindikasikan sama hal nya dengan demokratis bahwa pola asuh otoriter memiliki hubungan yang rendah dengan hedonisme dikarenakan tidak semua jenis pola asuh memilki keterkaitan dengan gaya hidup hedonisme. Dapat juga dikarenakan oleh faktor lain seperti pendidikan, pergaulan, dll.

Untuk pola asuh permisif tidak ditemukan hubungan dengan hedonisme, dikarenakan responden tidak ada yg memiliki gaya pola asuh yang menonjol. Sehingga dapat disimpulkan bahwa tidak ditemukan responden dengan gaya pola asuh permisif.

Analisis di atas menyimpulkan bahwa peran orang tua memiliki peranan terpenting untuk anaknya dalam pembentukan karakter dan sifat anak. Pendidikan paling penting dan utama bagi anak adalah keluarga. Orang tua harus mampu memberikan contoh gaya hidup yang baik bagi anaknya.

Hipotesis yang ditemukan dalam penelitian ini adalah: $\mathrm{Ha}: \mathrm{pxy} \neq 0 \rightarrow$ Pola asuh berhubungan dengan gaya hidup hedonis pada remaja di SMAN 9 BOGOR. 


\section{DAFTAR PUSTAKA}

Baumrind, D.B. 1995. Parenting Stylish. American Psychologikal Association. Michigan.

Geraldine, K., Wanei., et all. 2003. Perilaku Anak Usia Dini Cetakan ke-5. Kanisius. Yogyakarta. Gunarsa, S.D., Yulia, S.G. 2000. Psikologi Perkembangan Anak dan Remaja. Jakarta: BPK Gunung Mulia.

Sakinah. 2002. Media Muslim Muda. Elfata. Solo.

Santrock, J.W. 2007. Remaja Edisi 11 J ilid 1. Jakarta: Erlangga.

Surbakti, E.B. 2009. Kenalilah Anak Remaja Anda. Elex Media Komputindo. Jakarta.

Yusuf, S. 2004. Psikologi Perkembangan Anak dan Remaja. Rosdoi. Jakarta. 